\title{
1 Reassessment of ocean paleotemperatures during the Late Ordovician
}

\section{Bryce B. Barney ${ }^{1}$, and Ethan L. Grossman ${ }^{1}$}

$3 \quad{ }^{I}$ Department of Geology and Geophysics, Texas A\&M University, College Station, 4 Texas, USA

\section{SUPPLEMENTARY MATERIALS}

\section{Geological Setting}

Paleogeographic reconstructions place the Cincinnati Arch of North America in

9 the southern subtropics, approximately $23-27^{\circ} \mathrm{S}$, during the beginning of the Late

10 Ordovician (Scotese, 2016). At the time of deposition, an epeiric sea covered much of

11 Laurentia. The Taconic Orogeny along eastern Laurentia created the Appalachian

12 foreland basin. The Cincinnati Arch was a peripheral bulge within that basin (Fig. 1)

13 (Pope et al., 2012). Cool-water subtidal and peritidal carbonates were deposited on the

14 Jessamine Dome of the Cincinnati Arch throughout the Late Ordovician (Kolata et al.,

15 2001). Twenty-eight calcitic brachiopods were analyzed from these Late Ordovician

16 strata.

\section{Burial History}

$$
\text { Regional burial history studies using conodont CAI or vitrinite reflectance }
$$
suggest that these strata experienced burial temperatures lower than $90{ }^{\circ} \mathrm{C}$ during the 
21 indicating minimal burial ( $<1$ to $2 \mathrm{~km}$ ), with maximum burial temperatures of $<50$ to 90

$22{ }^{\circ} \mathrm{C}$ for the Upper Ordovician sediments during the Mississippian to the early Permian

23 (Epstein et al., 1977). Between 1.3 and $2 \mathrm{~km}$ of overlying Late Paleozoic sediments were

24 eroded during the Mesozoic and Cenozoic (Stearns and Reesman, 1986). This allowed

25 for a maximum burial depth of at most $2.4 \mathrm{~km}$, with maximum burial temperatures of

$26 \sim 85^{\circ} \mathrm{C}$.

\section{Diagenetic Evaluation}

A thin section of each sample was examined under standard optical microscopy

for breaks in the original crystal fabric, such as filled fractures, corrosion, and secondary

30 mineral phases (e.g., pyrite). Secondly, thin sections were viewed using

31 cathodoluminescence (CL) microscopy with a Technosyn 8200 MKII cold cathode

32 luminoscope. Samples were exposed to a beam current and voltage of 200-300 nA, and

$3310-15 \mathrm{kV}$, respectively, for 60 seconds (Roark et al., 2017). Enrichment of $\mathrm{Mn}^{2+}$ above

$34 \sim 25 \mathrm{ppm}$ in the crystal lattice of calcite causes orange luminescence (Mason, 1987),

which typically indicates diagenesis in brachiopod shells (Popp et al., 1986; Grossman et

al., 1996). This is because $\mathrm{Mn}^{2+}$ is uncommon in oxygenated bottom waters but very

common in anoxic ground and pore waters. Thus, unaltered areas of the shells should

consist of non-luminescent areas free of visible dissolution and cementation features.

39 Note that $\mathrm{Mn}^{2+}$ may not be incorporated in diagenetic calcite precipitated in oxic or iron-

40 free waters, thus it is important to confirm cathodoluminescence in cements and

41 texturally altered grains (Grossman, 1994). Using a gradational scale of 
43 luminescent (SL), cathodoluminescent (CL), or some combination. The five categories

44 are NL, NL/SL, SL, SL/CL, and CL (See Figure 6 in Grossman, 2012). Shells were

45 sampled from several NL shell areas or NL/SL areas when NL areas were unavailable.

46 As a supplement to the textural and CL examination, trace elements were used as

47 a secondary criterion of alteration within the brachiopod shells. Diagenetic alteration

48 can lead to an increase in $\mathrm{Fe}^{2+}$ and $\mathrm{Mn}^{2+}$ and a decrease in $\mathrm{Sr}^{2+}$. These trends are often

49 associated with depletions in $\delta^{13} \mathrm{C}$ and $\delta^{18} \mathrm{O}$ (Brand and Veizer, 1980; Brand et al.,

50 2012). For trace element analyses (Fe, $\mathrm{Mg}, \mathrm{Mn}, \mathrm{Na}$, and $\mathrm{Sr}$ ), aliquots of $\sim 110 \mu \mathrm{g}$ of

51 sample powder were reacted in $1.5 \mathrm{ml}$ of $2 \% \mathrm{HNO}_{3}$ solution for $>1$ hour prior to

52 analysis on a Thermo Scientific Element XR high-resolution inductively coupled plasma

53 mass spectrometer (HR-ICP-MS) at the R. Ken Williams '45 Radiogenic Isotope

54 Geosciences Laboratory at Texas A\&M University. To correct for instrument drift,

$55 \sim 0.115 \mathrm{ml}$ of $100 \mathrm{ppb}$ indium standard was added to each solution. Analytical sessions

56 included measurements of internal standards with known elemental concentrations.

57 Samples found with $\mathrm{Mn}^{2+}>150 \mathrm{ppm}$ or $\mathrm{Fe}^{2+}>400 \mathrm{ppm}$ were considered diagenetically

58 altered and were not used for paleotemperature calculations (Grossman and Joachimski, 59 2020).

60

\section{Standardization of Isotopic Analyses}

62 Fossil brachiopod samples were run from May 2019 to September 2020.

63 Brachiopod samples were run with the four ETH standards in a sample-to-standard ratio 
64 of $1: 1$. The collected data for carbonate standards and unknowns were inputted into

65 Easotope (John and Bowen, 2016) to calculate $\delta^{18} \mathrm{O}, \delta^{13} \mathrm{C}$, and $\Delta_{47}$ values. $\delta^{13} \mathrm{C}$ and $\delta^{18} \mathrm{O}$

66 values are reported versus VPDB, and $\Delta_{47}$ values are standardized within the "Carbon

67 Dioxide Equilibrium Scale" (CDES) (Dennis et al., 2011). These calculations used (1)

68 acid digestion fractionation factors for both $\delta^{18} \mathrm{O}$ (Kim et al., 2007) and $\Delta_{47}$ values

69 (Petersen et al., 2019), (2) ${ }^{17} \mathrm{O}$ correction (Brand et al., 2010), and (3) non-linearity

70 corrections related to the IRMS on which the analyses were performed (Dale et al.,

71 2014; Meckler et al., 2014). Propagation of uncertainty was computed using the Python

72 package D47crunch as recommended in Daëron, 2021.

73 Replicates were screened using multiple protocols as a means of QA/QC.

74 Replicates with $\delta^{13} \mathrm{C}$ or $\delta^{18} \mathrm{O}$ values falling outside $\pm 2 \sigma$ the mean of that sample were

75 discarded regardless of the $\Delta_{47}$ value. Peirce's criterion was then used to determine

76 outliers in the remaining $\Delta_{47}$ data set, which were then removed (Ross, 2003).

$78 \quad$ Reordering Assessment Model

The Monte Carlo simulation at the center of the reordering assessment model

80 utilizes the Python package isotopylog. This package allows for the prediction of $\Delta_{47}$

81 evolution when a specified activation energy distribution is subjected to time-

82 temperature history. The specified activation energy distribution changes based on which

83 reordering model is selected. This work uses the reordering model presented in

84 Hemingway and Henkes (2021) as it presents $\Delta_{47}$ reordering as a system of disordered

85 kinetic processes with multiple pseudo-first-order reactions co-occurring. Previous 
86 reordering models (Henkes et al., 2014; Stolper and Eiler, 2015) are specific cases of

87 disordered kinetics within the framework of this disordered kinetics model.

The Monte Carlo simulation first produces a random temperature from a statistically normal temperature distribution which provides a suitable representation of the original environment based on a modern analog. However, as shown in Figure S3, at a maximum burial temperature of $\leq 150^{\circ} \mathrm{C}$, temperatures back-calculated using our method show minimal deviation $\left(\leq 2^{\circ} \mathrm{C}\right)$ from the initial simulated temperatures regardless of initial simulation temperature $\left(15-35^{\circ} \mathrm{C}\right)$.

The randomly produced initial temperature is then converted into $\Delta_{47}$ space using a specified temperature calibration. We use the recalculated Kele et al. (2015) calibration from Bernasconi et al. (2018). The same $\Delta_{47}$ temperature calibration must be used in the Monte Carlo simulation and the calculation of temperatures from measured materials. Using two different temperature calibrations will introduce significant error to the backcalculated temperatures, the magnitude of which is dependent on the temperature calibration used.

The Monte Carlo simulation then prepares an activation energy $\left(\mathrm{E}_{\mathrm{a}}\right)$ distribution based on published data on $\Delta_{47}$ reordering (Passey and Henkes, 2012; Henkes et al., 2014; Stolper and Eiler, 2015; Brenner et al., 2018; Hemingway and Henkes, 2021). This study used the 'all calcite average' $\mu_{\mathrm{E}}$ and $\sigma_{\mathrm{E}}$ values presented in Hemingway and Henkes (2021). A randomized $\mathrm{E}_{\mathrm{a}}$ error factor ( $<1$ to $10 \%$ ) was then added to the $\mu_{\mathrm{E}}$ and $\sigma_{\mathrm{E}}$ values of the $\mathrm{E}_{\mathrm{a}}$ distribution to calculate differences in $\mathrm{E}_{\mathrm{a}}$ attributed to trace element 
107 contents, ionic impurities, and/or crystallographic defects (Henkes et al., 2014;

108 Hemingway and Henkes, 2021).

109 The model then inputs the specified time-temperature history and produces a

110 series of 500 linearly approximated steps between each of the defined time-temperature

111 points to create a continuous time path for the geologic_history tool of isotopylog. This

112 tool then simulates the evolution of the $\Delta_{47}$ bond signal based on the previously defined

$113 \quad \mathrm{E}_{\mathrm{a}}$ distribution and time-temperature history. This process is iterated 1000 times, and the

114 results of each iteration is exported to an Excel $^{\mathrm{TM}}$ file.

115

116

117

118

119

120

121

122

123

124

125 
127

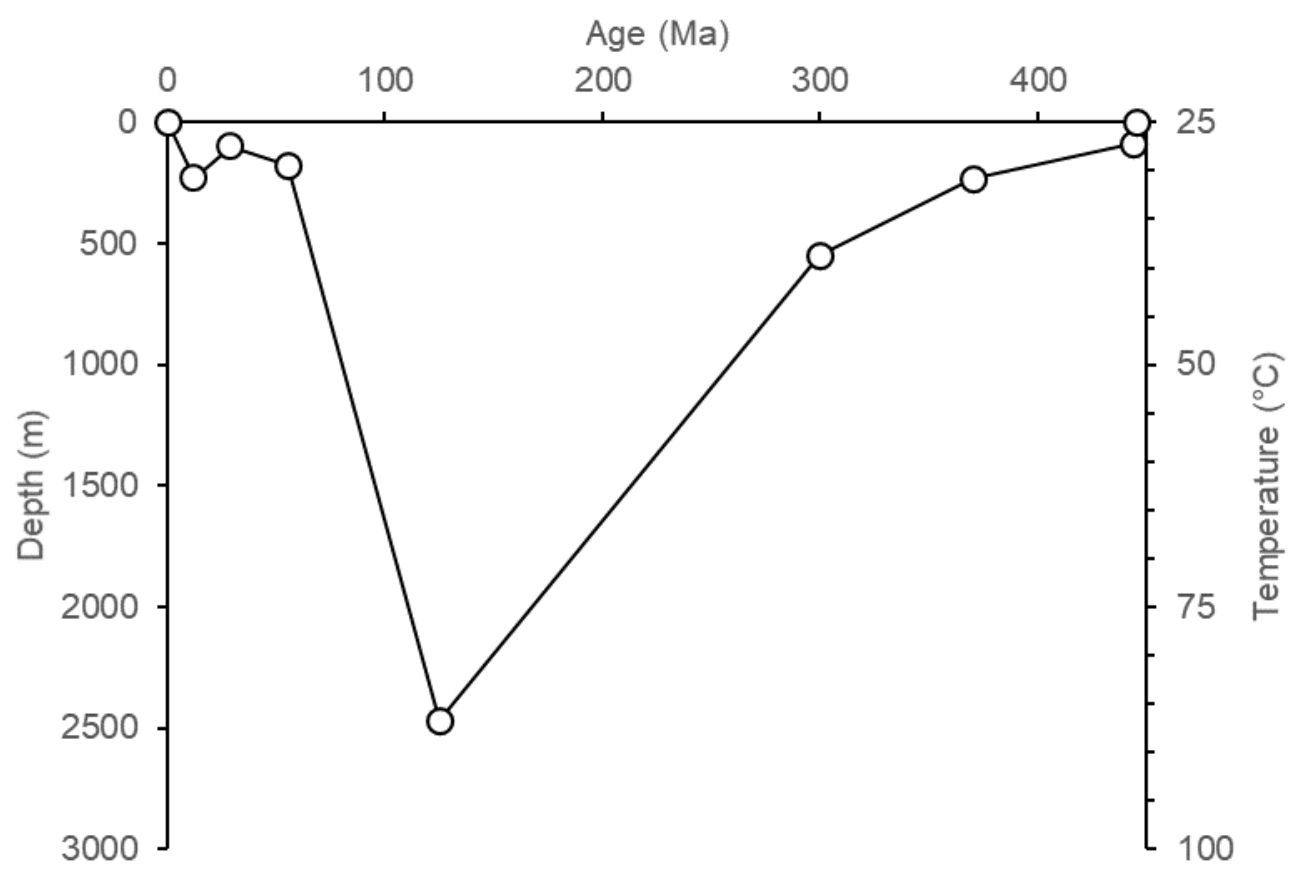

128 Figure S1. Time-temperature diagram for the Late Ordovician strata in the Cincinnati

129 Arch region (Stearns and Reesman, 1986; Ryder, 1987). 


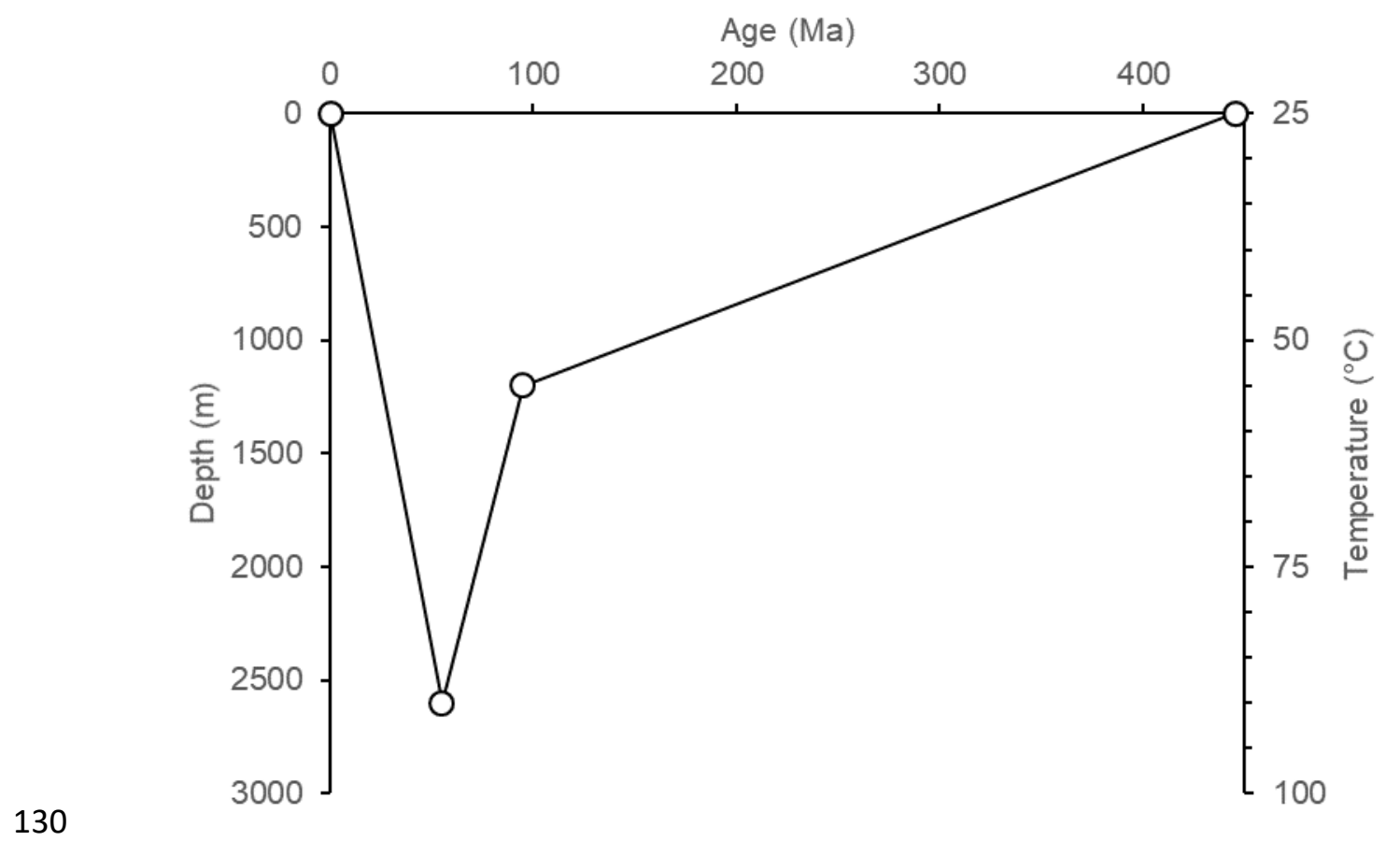

131 Figure S2. Time-temperature diagram for the Late Ordovician strata in the Anticosti

132 Island region (Bertrand, 1990).

133

134

135

136

137

138

139 


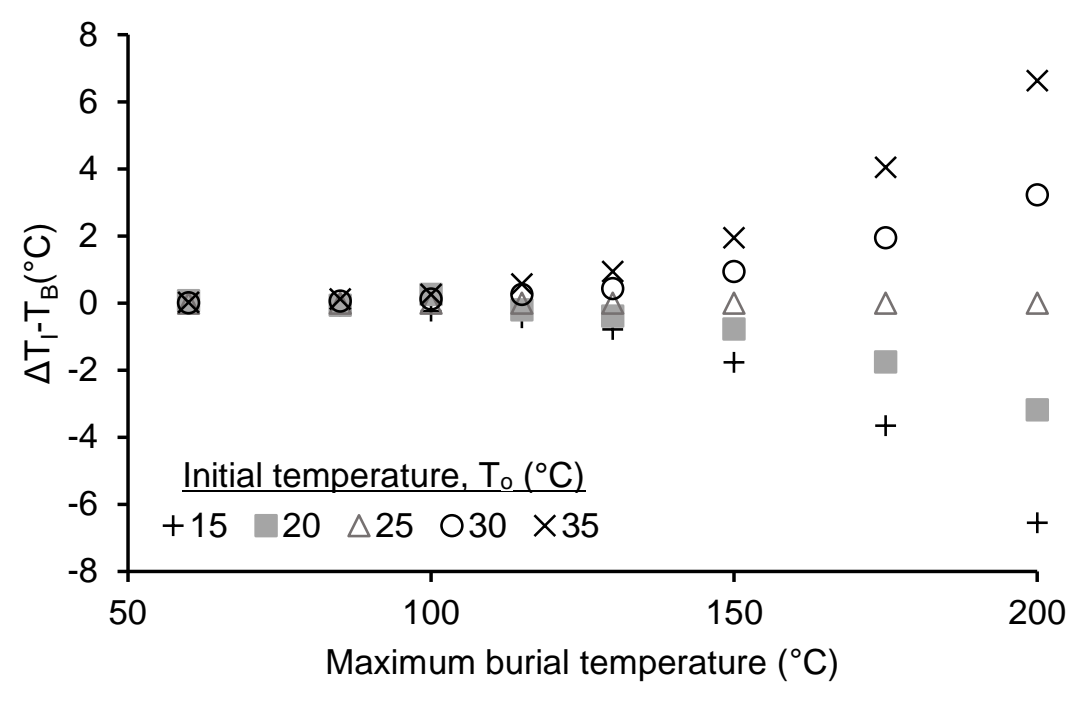

140

141 Figure S3. Difference between initial and back-calculated temperatures $\left(\Delta \mathrm{T}_{\mathrm{I}}-\mathrm{T}_{\mathrm{B}}\right)$ using

142 the $\Delta \mathrm{Tc}$ from a simulation with an initial temperature $\left(\mathrm{T}_{\mathrm{o}}\right)$ of $25 \pm 2{ }^{\circ} \mathrm{C}(\mathrm{N}=1000)$, as a

143 function of different hypothetical sample $\mathrm{T}_{\mathrm{o}}$ values and burial temperatures. Each

144 symbol characterizes a different hypothetical $\mathrm{T}_{\mathrm{o}}$ and the same burial history (Fig. S1).

145 Note that the uncertainty in back-calculated temperature related to assignment of the

146 initial temperature is small $\left( \pm 2{ }^{\circ} \mathrm{C}\right)$ at burial temperatures below $150{ }^{\circ} \mathrm{C}$.

147

148

149 


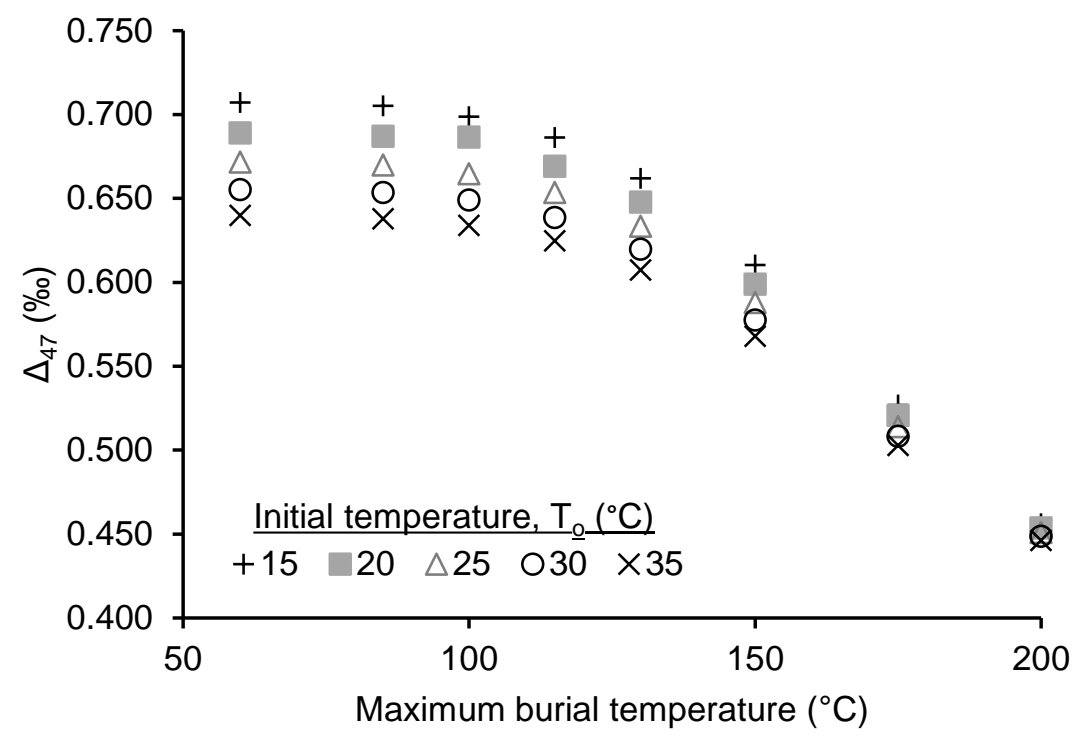

150

151 Figure S4. Simulated reordering of $\Delta_{47}$ versus maximum burial temperature using the

152 burial history shown in Figure S1. As in Figure S3, each symbol characterizes a different

153 hypothetical initial temperature $\left(\mathrm{T}_{0}\right)$. Note that the $\Delta_{47}$ values converge near the

154 equilibrium value at high temperature. 

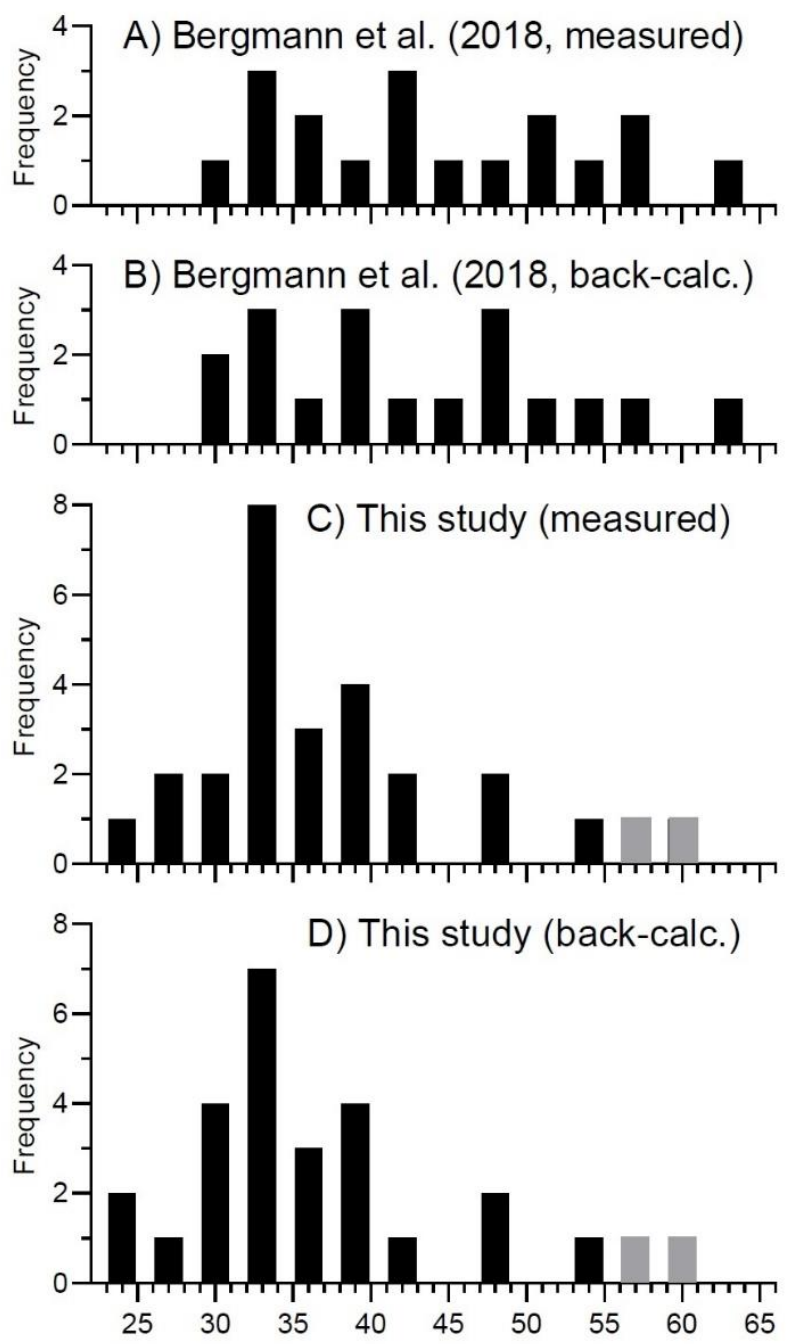

155 Figure S5. Histograms showing (A) measured brachiopod T( $\left.\Delta_{47}\right)$ from Bergmann et al.

156 (2018), (B) back-calculated brachiopod T( $\left.\Delta_{47}\right)$ from Bergmann et al. (2018), (C)

157 measured brachiopod T( $\left.\Delta_{47}\right)$ from this study, and (D) back-calculated brachiopod $\mathrm{T}\left(\Delta_{47}\right)$

158 from this study. Gray bars represent data outside $2 \sigma$ of the mean. 

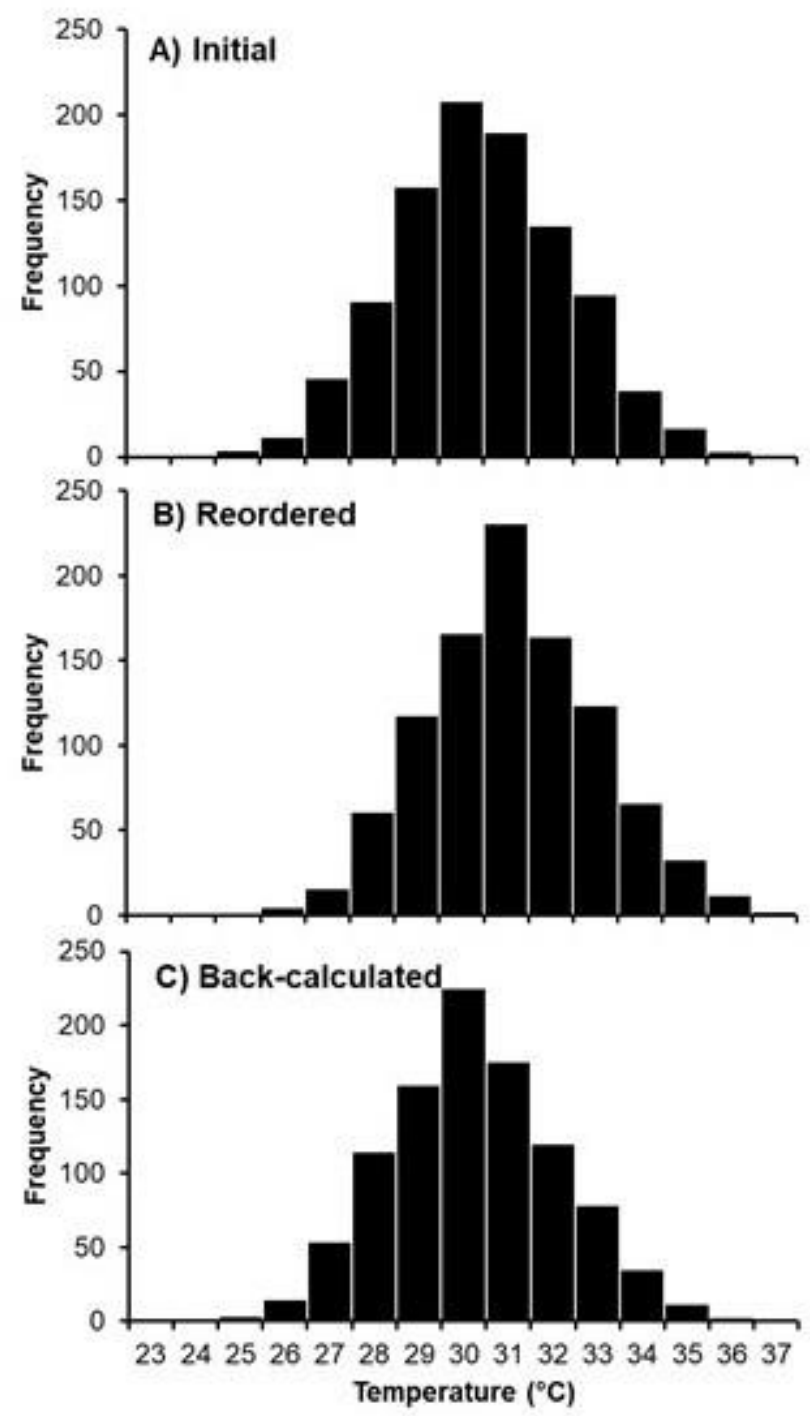

161 Figure S6. Histograms showing (A) Monte Carlo simulation of initial T( $\left.\Delta_{47}\right)$ values

162 (mean $\left.=30^{\circ} \mathrm{C}, 2 \sigma=2{ }^{\circ} \mathrm{C}, \mathrm{N}=1000\right)$, (B) impact of reordering on $\mathrm{T}\left(\Delta_{47}\right)$ values $(\mathrm{mean}=$ $16330.6^{\circ} \mathrm{C}, 2 \sigma=3.8^{\circ} \mathrm{C}$ ), using the model of Hemingway and Henkes (2021), and (C) back-

164 calculated $\mathrm{T}\left(\Delta_{47}\right)\left(\right.$ mean $\left.=29.7^{\circ} \mathrm{C}, 2 \sigma=3.8^{\circ} \mathrm{C}\right)$ using $\Delta \mathrm{Tc}$ correction of $0.9^{\circ} \mathrm{C}$

165 produced from the Monte Carlo simulation. 
Table S1. Trace element data and cathodoluminescence for measured brachiopods. $\mathrm{CL}=$ cathodoluminescent, $\mathrm{SL}=$ slightly luminescent, and $\mathrm{NL}=$ nonluminescent.

\begin{tabular}{ccccccc}
\hline \hline Sample & Fe (ppm) & Mg $(\mathbf{p p m})$ & $\mathbf{M n}(\mathbf{p p m})$ & $\mathbf{N a}(\mathbf{p p m})$ & $\mathbf{S r}(\mathbf{p p m})$ & $\mathbf{C L} \mathbf{r a t i n g}$ \\
\hline 65983 & 165 & 1338 & 112 & 487 & 384 & $\mathrm{CL}$ \\
OKP-1 & 228 & 1697 & 64 & 569 & 1777 & SL \\
OKH-1 & 139 & 1472 & 64 & 431 & 311 & NL/SL \\
66378 & 47 & 1104 & 20 & 523 & 292 & NL \\
27542 & 215 & 1220 & 227 & 459 & 327 & $\mathrm{CL}$ \\
68984 & 64 & 1049 & 26 & 711 & 716 & NL \\
CCSP-1 & 117 & 929 & 20 & 474 & 375 & NL \\
CCSP-2 & 166 & 1260 & 124 & 475 & 305 & SL/CL \\
27638 & 67 & 1140 & 40 & 560 & 562 & NL \\
$2142-1$ & 30 & 1261 & 10 & 616 & 508 & NL \\
27724 & 47 & 1082 & 78 & 585 & 790 & NL \\
51149 & 74 & 888 & 97 & 487 & 1513 & NL \\
51000 & 25 & 1100 & 22 & 492 & 350 & NL/SL \\
63678 & 50 & 1019 & 44 & 539 & 367 & NL \\
69459 & 193 & 1658 & 101 & 575 & 1191 & NL \\
$78682-2$ & 72 & 1198 & 9 & 538 & 714 & NL \\
63696 & 24 & 1182 & 69 & 562 & 314 & NL \\
78700 & 48 & 1662 & 11 & 621 & 513 & NL \\
$27909-1$ & 9 & 1064 & 7 & 599 & 284 & NL \\
27921 & 20 & 1282 & 26 & 656 & 436 & NL \\
MCP-1 & 55 & 1233 & 33 & 474 & 599 & N/SL \\
MCP-5 & 188 & 1511 & 156 & 643 & 442 & NL \\
MCH-1 & 237 & 1209 & 43 & 518 & 692 & SL \\
MCH-3 & 315 & 1150 & 208 & 459 & 139 & CL \\
$27969-1$ & 99 & 1721 & 114 & 659 & 594 & NL/SL \\
68818 & 41 & 999 & 7 & 523 & 349 & NL \\
68980 & 120 & 1335 & 125 & 455 & 212 & NL/SL \\
68766 & 27 & 920 & 10 & 427 & 188 & NL/SL \\
\hline & & & & &
\end{tabular}


Table S2. Back-calculated $\Delta_{47}$ temperatures of analyzed brachiopods (\%o) with reconstructed water $\delta^{18} O$ values.

\begin{tabular}{|c|c|c|c|c|c|c|c|c|c|}
\hline Sample & $\begin{array}{l}\text { Age } \\
\text { (Ma) }\end{array}$ & $\begin{array}{c}\text { Original } \\
\Delta 47 \mathrm{~T}\left({ }^{\circ} \mathrm{C}\right) * \\
\end{array}$ & $\begin{array}{c}95 \% \\
\text { CI } \\
\end{array}$ & $\begin{array}{c}\mathbf{H}_{2} \mathbf{O} \\
\delta^{18} \mathbf{O}_{\text {water }} \\
* * \\
\end{array}$ & $95 \% \mathrm{CI}$ & $\begin{array}{c}\Delta 47 \mathrm{~T} \\
\left(85^{\circ} \mathrm{C}\right) * \\
\end{array}$ & $\begin{array}{c}\mathrm{H}_{2} \mathrm{O} \delta^{18} \mathbf{O}_{\text {water }} \\
\left(85^{\circ} \mathrm{C}\right)^{\wedge} \\
\end{array}$ & $\begin{array}{c}\Delta_{47} \mathrm{~T} \\
\left(60^{\circ} \mathrm{C}\right)^{*} \\
\end{array}$ & $\begin{array}{c}\mathrm{H}_{2} \mathrm{O} \\
\delta^{18} \mathrm{O}_{\text {water }} \\
\left(60^{\circ} \mathrm{C}\right)^{\wedge} \\
\end{array}$ \\
\hline OKH-1 & 446.5 & 32 & 11 & -0.6 & 2.3 & 31 & -0.7 & 32 & -0.6 \\
\hline 66378 & 446.7 & 31 & 6 & -2.0 & 1.2 & 31 & -2.2 & 31 & -2.0 \\
\hline 68984 & 446.8 & 28 & 13 & -1.8 & 2.5 & 27 & -1.9 & 28 & -1.8 \\
\hline CCSP-1 & 446.9 & 57 & 8 & 3.3 & 1.6 & 56 & 3.2 & 57 & 3.3 \\
\hline 27638 & 447 & 34 & 9 & 0.0 & 1.8 & 33 & -0.2 & 34 & 0.0 \\
\hline $2142-1$ & 447 & 35 & 14 & -1.4 & 2.8 & 34 & -1.6 & 35 & -1.4 \\
\hline $2142-2$ & 447 & 40 & 10 & 0.3 & 2 & 39 & 0.1 & 40 & 0.3 \\
\hline 51149 & 447.2 & 49 & 6 & 2.2 & 1.2 & 48 & 2.0 & 49 & 2.2 \\
\hline 51000 & 447.3 & 33 & 15 & -1.0 & 2.9 & 32 & -1.2 & 33 & -1.0 \\
\hline 63678 & 447.3 & 35 & 11 & -0.2 & 2.2 & 35 & -0.5 & 36 & -0.3 \\
\hline 27909 & 447.7 & 34 & 11 & -0.9 & 2.2 & 33 & -1.0 & 34 & -0.9 \\
\hline MCH-1 & 447.8 & 30 & 12 & -1.2 & 2.4 & 29 & -1.4 & 30 & -1.2 \\
\hline MCP-5 & 447.8 & 37 & 9 & 0.3 & 1.7 & 36 & 0.0 & 37 & 0.2 \\
\hline $27969-1$ & 447.8 & 39 & 13 & 0.6 & 2.6 & 38 & 0.4 & 39 & 0.6 \\
\hline MCP-1-1 & 447.8 & 41 & 9 & 1.0 & 1.8 & 40 & 0.9 & 41 & 1.0 \\
\hline 27921 & 447.8 & 42 & 11 & 1.3 & 2.1 & 41 & 1.1 & 42 & 1.3 \\
\hline 27969-2 & 447.8 & 55 & 10 & 3.1 & 2 & 54 & 3.0 & 55 & 3.1 \\
\hline MCP-1-2 & 447.8 & 61 & 6 & 4.8 & 1.3 & 61 & 4.6 & 61 & 4.8 \\
\hline 68818 & 447.9 & 38 & 8 & 0.4 & 1.6 & 37 & 0.2 & 38 & 0.3 \\
\hline 68980 & 448.5 & 49 & 8 & 2.6 & 1.6 & 48 & 2.5 & 49 & 2.6 \\
\hline 68766 & 449 & 26 & 11 & -3.0 & 2.2 & 25 & -3.1 & 26 & -3.0 \\
\hline
\end{tabular}

*Calculated using Bernasconi et al. (2018) temperature calibration

${ }^{\wedge}$ Calculated using Kim and O'Neil (1997) calcite- $\mathrm{H}_{2} \mathrm{O}$ relationship 


\section{SUPPLEMENT REFERENCES}

Bernasconi, S.M., Müller, I.A., Bergmann, K.D., Breitenbach, S.F.M., Fernandez, A., Hodell, D.A., Jaggi, M., Meckler, A.N., Millan, I., and Ziegler, M., 2018, Reducing uncertainties in carbonate clumped isotope analysis through consistent carbonate-based standardization: Geochemistry, Geophysics, Geosystems, doi:10.1029/2017GC007385.

Bertrand, R., 1990, Maturation thermique et histoire de l'enfouissement et de la génération des hydrocarbures du bassin de l'archipel de Mingan et de l'île d'Anticosti, Canada: Canadian Journal of Earth Sciences, v. 27, p. 731-741, doi:10.1139/e90-075.

Brand, W.A., Assonov, S.S., and Coplen, T.B., 2010, Correction for the ${ }^{17} \mathrm{O}$ interference in $\delta^{13} \mathrm{C}$ measurements when analyzing $\mathrm{CO}_{2}$ with stable isotope mass spectrometry (IUPAC Technical Report): Pure and Applied Chemistry, v. 82, p. 1719-1733, doi:10.1351/PACREP-09-01-05.

Brand, U., Jiang, G., Azmy, K., Bishop, J., and Montañez, I.P., 2012, Diagenetic evaluation of a Pennsylvanian carbonate succession (Bird Spring Formation, Arrow Canyon, Nevada, U.S.A.) - 1: Brachiopod and whole rock comparison: Chemical Geology, v. 308-309, p. 26-39, doi:10.1016/J.CHEMGEO.2012.03.017.

Brand, U., and Veizer, J., 1980, Chemical Diagenesis of a Multicomponent Carbonate System-1: Trace Elements: Journal of Sedimentary Petrology, v. 50, p. 1219-1236, http://citeseerx.ist.psu.edu/viewdoc/download?doi=10.1.1.857.865\&rep=rep1\&type=pdf (accessed July 2019).

Brenner, D.C., Passey, B.H., and Stolper, D.A., 2018, Influence of water on clumped-isotope bond reordering kinetics in calcite: Geochimica et Cosmochimica Acta, v. 224, p. 42-63, doi:10.1016/j.gca.2017.12.026.

Daëron, M., 2021, Full propagation of analytical uncertainties in $\Delta_{47}$ measurements: Geochemistry, Geophysics, Geosystems, v. 22, p. 1-19, doi:10.1029/2020GC009592.

Dale, A., John, C.M., Mozley, P.S., Smalley, P.C., and Muggeridge, A.H., 2014, Time-capsule concretions: Unlocking burial diagenetic processes in the Mancos Shale using carbonate clumped isotopes: Earth and Planetary Science Letters, v. 394, p. 30-37, doi:10.1016/j.epsl.2014.03.004.

Dennis, K.J., Affek, H.P., Passey, B.H., Schrag, D.P., and Eiler, J.M., 2011, Defining an absolute reference frame for "clumped" isotope studies of $\mathrm{CO}_{2}$ : Geochimica et Cosmochimica Acta, v. 75, p. 7117-7131, doi:10.1016/j.gca.2011.09.025.

Epstein, A.G., Epstein, J.B., and Harris, L.D., 1977, Conodont Color Alteration - an Index to Organic Metamorphism:, doi:10.1130/0016-7606(1987)99<471:CCATAA>2.0.CO;2.

Grossman, E.L., 2012, Applying Oxygen Isotope Paleothermometry in Deep Time: The Paleontological Society Papers, v. 18, p. 39-68, doi:10.1017/s1089332600002540.

Grossman, E.L., and Joachimski, M.M., 2020, Oxygen Isotope Stratigraphy, in Geologic Time Scale 2020, Elsevier, p. 279-307, doi:10.1016/b978-0-12-824360-2.00010-3. 
Grossman, E.L., Mii, H.-S., Zhang, C., and Yancey, T.E., 1996, Chemical variation in Pennsylvanian brachiopod shells - Diagenetic, taxonomic, microstructral, and seasonal effects: Journal of Sedimentary Research, v. 66, p. 1011-1022.

Hemingway, J.D., and Henkes, G.A., 2021, A disordered kinetic model for clumped isotope bond reordering in carbonates: Earth and Planetary Science Letters, v. 566, p. 116962, doi:10.1016/j.eps1.2021.116962.

Henkes, G.A., Passey, B.H., Grossman, E.L., Shenton, B.J., Pérez-Huerta, A., and Yancey, T.E., 2014, Temperature limits for preservation of primary calcite clumped isotope paleotemperatures: Geochimica et Cosmochimica Acta, v. 139, p. 362-382, doi:10.1016/j.gca.2014.04.040.

John, C.M., and Bowen, D., 2016, Community software for challenging isotope analysis: First applications of 'Easotope' to clumped isotopes: Rapid Communications in Mass Spectrometry, v. 30, p. 2285-2300, doi:10.1002/rcm.7720.

Kim, S.-T., Mucci, A., and Taylor, B.E., 2007, Phosphoric acid fractionation factors for calcite and aragonite between 25 and $75^{\circ} \mathrm{C}$ : Revisited: Chemical Geology, v. 246, p. 135-146, doi:10.1016/J.CHEMGEO.2007.08.005.

Kolata, D.R., Huff, W.D., and Bergström, S.M., 2001, The Ordovician Sebree Trough: An oceanic passage to the Midcontinent United States: Geological Society of America Bulletin, v. 113, p. 1067-1078, doi:10.1130/0016-7606(2001)113<1067:TOSTAO>2.0.CO;2.

Meckler, A.N., Ziegler, M., Millán, M.I., Breitenbach, S.F.M., and Bernasconi, S.M., 2014, Long-term performance of the Kiel carbonate device with a new correction scheme for clumped isotope measurements: Rapid Communications in Mass Spectrometry, v. 28, p. 1705-1715, doi:10.1002/rcm.6949.

Passey, B.H., and Henkes, G.A., 2012, Carbonate clumped isotope bond reordering and geospeedometry: Earth and Planetary Science Letters, v. 351-352, p. 223-236, doi:10.1016/j.epsl.2012.07.021.

Petersen, S. V. et al., 2019, Effects of improved ${ }^{17} \mathrm{O}$ correction on interlaboratory agreement in clumped isotope calibrations, estimates of mineral-specific offsets, and temperature dependence of acid digestion fractionation: Geochemistry, Geophysics, Geosystems, v. 20, p. 3495-3519, doi:10.1029/2018GC008127.

Pope, M.C., Holland, S.M., and Patzkowsky, M.E., 2012, The Cincinnati Arch: A stationary peripheral bulge during the Late Ordovician: Perspectives in Carbonate Geology, v. 2812, p. 255-275, doi:10.1002/9781444312065.ch16.

Popp, B.N., Anderson, T.F., and Sandberg, P.A., 1986, Brachiopods as indicator of original isotopic composition in some Paleozoic limestones: Bulletin of the Geological Society of America, v. 97, p. 1262-1269, doi:10.1130/0016-7606(1986)97<1262.

Roark, A., Flake, R., Grossman, E.L., Olszewski, T., Lebold, J., Thomas, D., Marcantonio, F., Miller, B., Raymond, A., and Yancey, T., 2017, Brachiopod geochemical records from across the Carboniferous seas of North America: Evidence for salinity gradients, stratification, and circulation patterns: Palaeogeography, Palaeoclimatology, Palaeoecology, 
v. 485, p. 136-153, doi:10.1016/j.palaeo.2017.06.009.

Ross, S.M., 2003, Peirce's criterion for the elimination of suspect experimental data: Journal of Engineering Technology, v. 20, p. 38-41.

Ryder, R.T., 1987, Oil and gas resources of the Cincinnati Arch, Ohio, Indiana, Kentucky, and Tennessee. U.S. Geological Survey Open-File Report 87-450Y:, doi:https://doi.org/10.3133/ofr87450Y.

Scotese, C.R., 2016, PALEOMAP PaleoAtlas for GPlates and the PaleoData Plotter Program: Updated at: https://www. earthbyte. org/paleomap-paleoatlas-for-gplates/, accessed, v. 1.

Stearns, R.G., and Reesman, A.L., 1986, Cambrian To Holocene structural and burial history of Nashville Dome.: American Association of Petroleum Geologists Bulletin, v. 70, p. 143154, doi:10.1306/94885647-1704-11d7-8645000102c1865d.

Stolper, D.A., and Eiler, J.M., 2015, The kinetics of solid-state isotope-exchange reactions for clumped isotopes: A study of inorganic calcites and apatites from natural and experimental samples: American Journal of Science, v. 315, p. 363-411, doi:10.2475/05.2015.01. 